\section{THE TRANSANDINE RAILWAY.}

$I^{T}$ was on March 29, 1835, that Charles Darwin, who had reached Mendoza from Valparaiso by Peuquenes and Portillo, set out on his return journey across the Andes by the more northern line of the Uspallata and

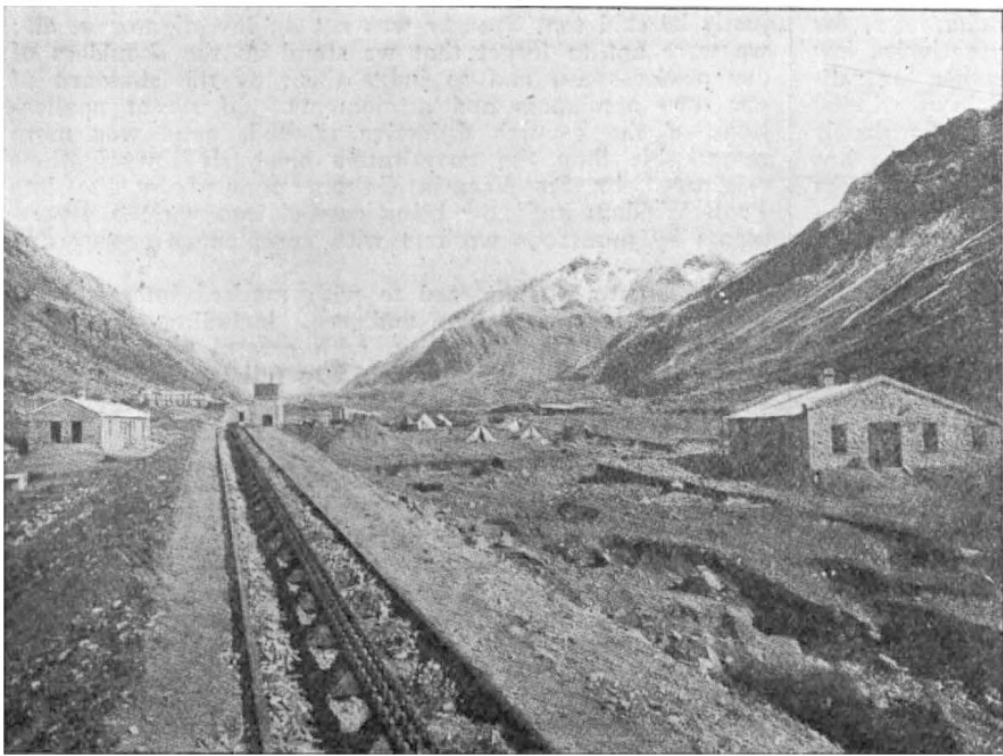

Fig. r.-Valley of the Rio Mendoza below Puente del Inca, looking up stream; the rack rail is $\mathrm{s}$ en in the foreground. 1

Cumbre passes, which has always been the principal means of communication between the pampas and the Pacific Coast. It was not until twelve days later that he reached Santiago, though no doubt a less ardent geologist might have completed the journey in somewhat shorter time. It could now be easily accomplished by rail in less than the same number of hours.

The Transandine railway is constructed un the metre gauge, like many of the Indian lines, although it links up two broad-gauge systems. Leaving Mendoza, where it connects with the Argentine Great Western at a height of 2700 feet above the sea, it turns southward across the plain, making for the point where the Rio Mendoza leaves the eastern or Uspallata range of the Andes, and then follows the windings of the deep river valley through the mountains. It thus takes a route somewhat to the south of that by which Darwin and other travellers crossed this range. According to their descriptions, the eastern slopes are composed of Rhætic sandstones and bituminous shales resting on Devonian and Ordovician slates, such as are found in many parts of the Andes. These are covered unconformably still further to the westward by thousands of feet of acid and basic lavas and tuffs interstratified with sandstones and carbonaceous shales, and believed to be of Tertiary age. Intrusions of granite and porphyry also occur.

After emerging from these mountains and traversing the Uspallata Pampa, a plateau of coarse detritus at an altitude of 6000 feet, the railway enters the central cordillera of the Andes by the deep gorge of what may still be called the Rio Mendoza, though, like most South American rivers, it is known by

1 The illustrations are reproduced, with permission, from a raper by $\mathrm{Mr}$. W. S. Barclay in the November number of the Geographical Journal. NO. 2 I 6 6. VOL. 85 different names in different parts of its course. Here the slates are covered apparently conformably by a thick succession of Mesozoic rocks described in detail by Darwin, Stelzner, and Schiller. They include acid lavas and tuffs, breccias and conglomerates of the same material passing into arenaceous rocks, amygdaloidal basalt, limestones, sypsum interstratified with red and purple sandstones and conglomerates, and finally lava flows, tuffs, and conglomerates, consisting mainly of andesite, which are probably of late Cretaceous or even early Tertiary age. Although marine fossils of Jurassic and Cretaceous types are net with, some of the beds were probably laid down under continental conditions. On the east the rocks are much disturbed, and are penetrated and motamorphosed by granite and diorite, as well as by minor inclusions, which traverse, not only the stratified, but the plutonic rocks.

The sides of the gorge present magnificent sections of the geological structure, one of the finest of which is at the mouth of the IIorcones valley, by which Aconcagua was successfully ascended. At Las Cuevas, a little further on, the train enters the tunnel beneath the Cumbre ("summit") pass and emerges in the valley of a tributary of the Rio Aconcagua, which makes its way westward to the Pacific. The tunnel is less than two miles long, and little more than 10,000 feet above the sea, while the pass is some 2000 feet higher. It is stated to have been excavated in limestone and sypsum, and conglomerates of rocks of igneous origin. The western slopes of the ridge are exposed to the wet north-west winds, and the rocks are in places saturated with water and decomposed, so that it was necessary to face the interior of the tunnel with concrete.

The railway then follows the valley of the Aconcagua,

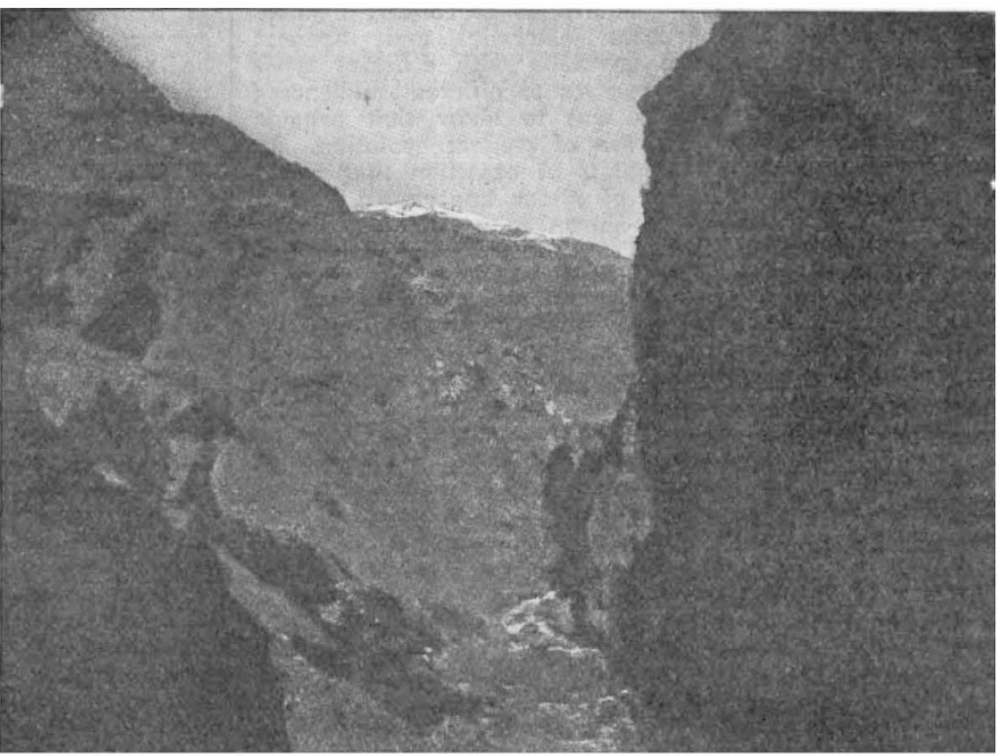

FIG. 2.-Scenery on the Chilian side of the tunnel.

where the later volcanic rocks dip at moderate angles to the westward, and are penetrated here and there by intrusions of " porphyry," down to the fertile plain of the same name, where at Santa Rosa de los Andes it connects with the State railways of Chile. On account of the steepness of the valley slopes and the decomposition of 
the rocks the construction of the line on the western slope presented serious problems to be solved, and the central rack rail is almost continuously employed for a distance of fifteen miles, while on the Argentine side it is only occasionally resorted to.

Nearer the equator, where south-easterly winds prevail, there are railways which, starting from the Pacific Coast, reach an altitude of more than 14,000 feet without the use of any special appliance of this character, for the rainless western slopes present comparatively few engineering difficulties; but when the time comes for railways to be built down to the Amazonian plain it will be no easy task to construct a firm track through the deeply dissected country, where the almost continuous rain has decomposed the rock to a considerable depth, and from time to time sreat landslips leave a strip of the valleyside denuded from crest to base of its thick covering of trees.

The opening of this through route from the Atlantic to the Pacific is an important step in the development of communications in South America. Soon the Argentine railways will be rinited to those of Bolivia and Peru, and the lowlands of Bolivia rendered accessible by the railway round the cataracts of the Madeira. Everywhere the plateau, the pampa, and the forest are losing their remoteness and their solitude, and bid fair to be occupied, ere long, with a population drawn from European sources, a consummation that, however natural and inevitable it may be, cannot but inspire some vain regrets in those who have known them when they were still in the state in which the early Spanish adventurers found them.

\section{John W. Evans}

EVOLUTION : DAR WINIAN AND SPENCERIAN.

$\mathrm{O}^{\mathrm{N}}$ Thursday, December 8 , the Herbert Spencer lecture at Oxford was delivered by Prof. Meldola, F.R.S., the title of the lecture being "Evolution: Darwinian and Spencerian." Prof. Meldola began by pointing out that while Oxford had influenced Darwin through Lyell (whose reputation, however, was made by throwing over the doctrine of his old master at Oxford, Buckland), it had also influenced Spencer through both Lyell and Mansel. Evolution, the lecturer proceeded, did not stand or fall with natural selection, but the prominence given by Darwin to the latter principle availed to convert Spencer from exclusive Lamarckism. Darwin and Spencer approached the problem of evolution with different types of mind, and addressed themselves to different audiences; the special task of Spencer was to show that organic evolution was a particular case of general evolution. In this he entirely succeeded, points of objection that might be taken to his views being of minor importance. Selection, so far, had only been shown to prevail in relation to the phenomena of life. Darwin's influence in departments where selection is not found was only indirect.

There was a fundamental difference in the method of attack of scientific problems adopted by Darwin and Spencer respectively. The procedure of the former was analytic, that of the latter synthetic. For Spencer, philosophy was unified science. His treatment of scientific questions was characterised by extreme breadth, inasmuch as his principles transcended the data of particular sciences, this being one reason why he failed to impress scientific men so much as might have been expected. No such attempt to wield the weapon of unified science had ever before been made. In estimating the comparative validity of the methods employed by the two men, it should be remembered that Darwin was working at a lower level; thus his foundations were more securely laid; and however sound the method, information can, after all, only be acquired by beings of finite intelligence and imperfect sense organs. Hence mistakes could be, and actually were, made; these, however, the same method would be competent to correct in the presence of better information. Spencer's plan, on the other hand, was to prove the existence of underlying principle controlling all the processes of nature. Hence his method was philosophical in the more enlightened sense of that term-the sense seen in the old expression " natural philosophy."

From this point of view the division between sciences, though convenient, is arbitrary. The role of the philo-

$$
\text { NO. } 2 \text { I } 46 \text {, VOL. } 85]
$$

sopher is to develop generalisations and present them for verification by science. Hence the sphere of science is different from that of philosophy; and in the region of physical phenomena the deductive method has never been called in question. In conversation with Darwin, the lecturer was once speaking of the difficulties attendant on the interrogation of Nature, to which Darwin replied, "She will tell you a direct lie if she can"! It could not justly be said that Spencer was not an investigator at all; we were apt to forget that we stand on the shoulders of our predecessors, and to judge them by the standard of our own appliances and attainments. Of recent applications of the genuine deductive method, none was more remarkable than the quantitative biometric investigations originated by Sir Francis Galton, pursued by the late Prof. Weldon, and now being carried into various departments by numerous workers with conspicuous energy and success.

The lecture was listened to with marked interest by a large and representative audience, including the ViceChancellor of the University, with several professors and heads of colleges. It is published in full by the Clarendon Press.

\section{THE WORK OF POLYTECHNIC INSTITUTES.}

THE Lord Chief Justice, Lord Alverstone, G.C.M.G.

P.C., distributed the prizes at the annual prize distribution at the Northampton Polytechnic Institute, London, E.C., on Thursday, December 8. In the course of his address, after the distribution of the prizes, he remarked that one reason why perhaps years ago we had fallen back was that this country and this metropolis had not then been aroused to the necessity of thoroughly good technical education, but that now immense good had been done to all the outlying districts of the metropolis, as well as to the City itself, by the establishment of the great polytechnics and by their capability for doing good work and of leading their students to higher and better grades. With reference to the proposed establishment of a great institution of technical optics in connection with the Northampton Polytechnic, he recalled a visit he paid years ago to the workshops of Messrs. Beck, and was satisfied that with the development of science that was now going forward practical optics would take a very prominent place in the future; he hoped that the polytechnic, with the support of those interested in it and the support of public bodies, would be able to say next year that the building of the new optical school had been commenced. It was always, he considered, a matter of regret when the educational facilities of any branch of technical industry were cribbed, cabin'd, and confined, and he further expressed the opinion that it was of very great importance that any school of practical technology or practical instruction in any expert business should be able to command the best apparatus and the best accommodation, because if it did not it would soon take second place. In these days specialisation is absolutely necessary in every trade, and after the preliminary training in fundamental subjects the time soon comes when specialisation must begin with the students, for in the present day it is no good scratching at a subject, but it must be gone through right to the bottom, so that the higher branches may be developed. Rapid modern developments, for instance, in electricity are constantly calling upon the institution for better apparatus, upon the teachers for greater acquirements, and upon the students for greater application.

After reference to the expenditure of some $6000 l$. on the new electric generating station, the Lord Chief Justice reminded the governors that they must be prepared for change if they desired to keep up the standard of the institution to the highest possible point. They must be on the look-out in each subject for the particular branches which can be specialised. In speaking to the students of the necessity for concentration on the object in view, he remarked that the extraordinary thing about Faraday was that he seemed to be able to think and think only of the particular subject that he was studying, and if he saw a light by the way which perhaps might lead him to some other aim or object he did not follow it up at once, but made a note, so to speak, in his mind, never forgetting the main object at which he was aiming, but putting a little mark so as to 